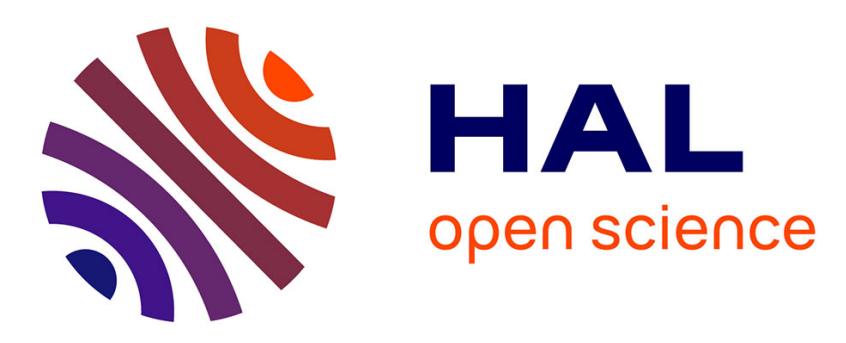

\title{
Weathering of ammonium- or calcium-saturated 2:1 phyllosilicates by ectomycorrhizal fungi in vitro
}

Franck Paris, Pascal Bonnaud, Jacques J. Ranger, M. Robert, Frédéric

Lapeyrie

\section{- To cite this version:}

Franck Paris, Pascal Bonnaud, Jacques J. Ranger, M. Robert, Frédéric Lapeyrie. Weathering of ammonium- or calcium-saturated 2:1 phyllosilicates by ectomycorrhizal fungi in vitro. Soil Biology and Biochemistry, 1995, 27 (10), pp.1237-1244. hal-02708093

\section{HAL Id: hal-02708093 \\ https://hal.inrae.fr/hal-02708093}

Submitted on 1 Jun 2020

HAL is a multi-disciplinary open access archive for the deposit and dissemination of scientific research documents, whether they are published or not. The documents may come from teaching and research institutions in France or abroad, or from public or private research centers.

$$
\text { Copyright }
$$

L'archive ouverte pluridisciplinaire HAL, est destinée au dépôt et à la diffusion de documents scientifiques de niveau recherche, publiés ou non, émanant des établissements d'enseignement et de recherche français ou étrangers, des laboratoires publics ou privés. 


\title{
WEATHERING OF AMMONIUM- OR CALCIUM-SATURATED 2:1 PHYLLOSILICATES BY ECTOMYCORRHIZAL FUNGI IN VITRO
}

\author{
FABIENNE PARIS,' PASCAL BONNAUD, ${ }^{2}$ JACQUES RANGER, ${ }^{2}$ \\ MICHEL ROBERT ${ }^{3}$ and FREDERIC LAPEYRIE ${ }^{i *}$
}

Laboratoires ${ }^{1} \mathrm{de}$ Microbiologie et ${ }^{2} \mathrm{~d}$ 'Etude des Cycles Biogéochimiques, INRA, Centre de Recherches Forestières de Nancy,Champenoux, 54280 Seichamps, France and ${ }^{3}$ Station de Scicnccs du Sol 2 , INRA, route de St Cyr, 78026 Versailles, France

(Accepted 24 March 1995)

\begin{abstract}
Summary-The ways through which ectomycorrhizal fungi benefit tree growth and nutrition have not been totally elucidated. Our study was therefore aimed at asscssing fungal access to soil exchangeable and stable mineral reserves. The growth of different ectomycorrhizal fungi in bi-compartment Petri dishes with $\mathrm{NH}_{4}^{+}$or Ca-saturated vermiculite led to cation exchange reactions and to crystal lattice weathering. The presence or absence of soluble $\mathrm{NH}_{4}^{+}$or $\mathrm{Ca}$ did not seem to affect fungal mobilization potential. Oxalic acid appears to be involved in vermiculite weathering by Paxillus involutus and $\mathrm{Ca}$ ions could limit the acid dissolution of $\mathrm{Ca}$-saturated vermiculite. The quantitative significance of such cation mobilization and mineral weathering still has to be assessed in situ and in association with ectomycorrhizal plants.
\end{abstract}

\section{INTRODUCTION}

Ectomycorrhizal fungi benefit tree growth and nutrition: plants inoculated with efficient ectomycorrhizal fungi grow faster than non-mycorrhizal plants, their shoot-to-root ratio is often larger and their nutrient concentration is sometimes increased compared to non-inoculated plants (Harley and Smith, 1983; Le Tacon et al., 1988; Dixon and Hiol-Hiol, 1992). These common observations suggest that infected roots are more efficient per unit weight or length in extracting soil minerals than non-mycorrhizal ones. The mechanisms through which they develop such an efficiency have not been totally elucidated. It is most probably due to improved soil colonization. Infected root systems are well-adapted, both in terms of total length and branching pattern, to exploit the volume of soil in which they develop. Extramatricial hyphae, strands or rhizomorphs associated with ectomycorrhizas extend out into the soil beyond the root absorbing zone and form a complex mycorrhizal system of branches (Bowen, 1973). Yet, ectomycorrhizal fungi could also be directly involved in the nutrient cycling of forest ecosystems: they contribute to $\mathrm{N}$ translocation betwen trees connected by a common ectomycorrhizal mycelium (Arnebrant et al., 1993), and could enhance nutrient availability through biochemical solubilization and chelation of exchangeable or stable mineral reserves.

Most of the work concerned with soil mineral-

*Author for correspondence. microorganism interactions has focused so far on saprophytic fungi, bacteria or lichens (Eckhard, 1985; Jones and Wilson, 1985; Robert and Berthelin, 1986). One might assume that ectomycorrhizal fungi possess qualitatively the same properties as non-symbiotic rhizosphere soil microorganisms; however, as symbiotic fungi are directly connected to large sinks (i.e. the host plants), their contribution to plant nutrition could be quantitatively much more significant. Whatever hypothesis is prevalent in situ, symbiotic hyphae directly contribute to plant mineral nutrition; it is therefore essential to assess fungal access to the soil mineral compartment. The mineral nutrition of the host plant might depend more on hyphae-soil interface characteristics, than on root-soil interactions.

Ectomycorrhizal fungi are able to solubilize poorly-soluble phosphates in vitro (Bousquet et al., 1985; Leyval and Berthelin, 1986; Lapeyrie et al., 1991; Nguyen et al., 1992), but there is still some controversy about whether or not they are able to give the plant access to new phosphate sources in soil (Thomas et al., 1982). There is also some evidence that mycorrhizal fungi contribute to phlogopite alteration and to potassium mobilization in soil (Leyval and Berthelin, 1991; Hinsinger and Jaillard, 1993), but no information is available concerning mycorrhizal access to $\mathrm{NH}_{4}^{+}$or $\mathrm{Ca}^{2+}$ ions from clay minerals.

According to Paul and Clark (1989), the amount of fixed $\mathrm{NH}_{4}^{+}$in the top meter of soil increases from 5 to $13 \%$ of the total $\mathrm{N}$ in surface horizons to $50 \%$ of the total $\mathrm{N}$ in subsurface horizons. Stevenson et al. (1958) reported that in some subsoil samples as much as $70 \%$ 
of $\mathrm{NH}_{4}^{+}$could be part of clay complexes. In acidic soils, an exchangeable pool often represents the main source of available $\mathrm{Ca}$ for vegetation, this pool being maintained only by a very conservative biological cycle (low weathering rates and atmospheric inputs). Our aim was therefore to determine in vitro whether or not some ectomycorrhizal fungi have access to $\mathrm{NH}_{4}^{+}$ or $\mathrm{Ca}$ trapped inside vermiculite interlayer space and how nutritional conditions influence their potential.

\section{MATERIALS AND METHODS}

\section{Materials}

Fungal strains. Experiments were conducted with Paxillus involutus strain COU (isolated under Eucalyptus in France). Six other ectomycorrhizal strains were used for comparison: $P$. involutus strain NAU, Boletus edulis strain BARL, Cenococcum geophilum strain SIV, Hebeloma cylindrosporum strain D15, Pisolithus tinctorius strain 441 and Rhizopogon luteolus strain KTP.

Vermiculite characteristics. The mineral used was a reference vermiculite collected at Santa Ollala (Spain) having the following structural formula:

$$
/ \mathrm{Si}_{2.72} \mathrm{Al}_{1.28} / / \mathrm{Al}_{0.06} \mathrm{Fe}_{0.24}^{3} \mathrm{Fe}_{0.03}^{2} \mathrm{Mg}_{2.59} \mathrm{Ti}_{0.08} / \mathrm{Ca}_{0.41} \mathrm{O}_{10}(\mathrm{OH})_{2} \text {. }
$$

It has a high cation exchange capacity (CEC): 160 mequiv $100 \mathrm{~g}^{-1}$ mineral.

Mineral preparation. Vermiculite was ground, sieved (50-100 $\mu \mathrm{m})$ and washed with distilled water. To avoid interactions, quartz and ferrous oxides were removed by magnetic separation. Vermiculite purity was checked under a photonic microscope. The mineral was sterilized by $\gamma$-radiations $(20 \mathrm{kGy})$ before saturation under sterile conditions with $\mathrm{NH}_{4}^{+}$or $\mathrm{Ca}^{2+}$ cations. Vermiculite $(10 \mathrm{~g})$ was suspended $\left(37^{\circ} \mathrm{C}\right.$,

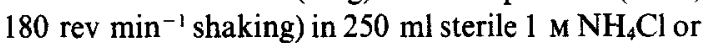
$\mathrm{CaCl}_{2}$ solutions. The incubation solutions were renewed every day for 8 days. Saturated vermiculite was finally rinsed in $4 \times 250 \mathrm{ml}$ of sterile distilled water and air-dried under a laminar flow beam.

\section{Experimental device}

To avoid any exchange of vermiculite interfoliar cations with cations from the nutrient medium, fungi were grown in bi-compartment Petri dishes $(100 \mathrm{~mm}$ dia).

The first compartment was filled with basic low glucose nutrient agar medium $\left[\left(\mathrm{NH}_{4}\right)_{2} \mathrm{SO}_{4}, 1.250 \mathrm{~g}^{-1}\right.$; $\mathrm{NaH}_{2} \mathrm{PO}_{4} .2 \mathrm{H}_{2} \mathrm{O}, \quad 869 \mathrm{mg} \mathrm{l}^{-1} ; \quad \mathrm{KCl}, \quad 275 \mathrm{mg} \mathrm{l}^{-1}$; $\mathrm{MgSO}_{4} .7 \mathrm{H}_{2} \mathrm{O}, 150 \mathrm{mg} \mathrm{l}^{-1} ; \mathrm{CaCl}_{2} .2 \mathrm{H}_{2} \mathrm{O}, 50 \mathrm{mg} \mathrm{l}^{-1}$; trace element stock solution (Kanieltra $6 \mathrm{Fe}$, Hydro Azote Co, France: $\mathrm{Fe}, 6.00 \mathrm{~g} \mathrm{l}^{-1}$; $\mathrm{Mo}, 0.27 \mathrm{~g} \mathrm{l}^{-1} ; \mathrm{B}_{2} \mathrm{O}_{3}$, $8.45 \mathrm{~g} \mathrm{l}^{-1} ; \mathrm{Mn}, 5.00 \mathrm{~g} \mathrm{l}^{-1} ; \mathrm{Cu}, 625 \mathrm{mg} \mathrm{l}^{-1} ; \mathrm{Zn}$, $\left.2.27 \mathrm{~g} \mathrm{l}^{-1}\right), \quad 0.1 \mathrm{ml} \mathrm{l}^{-1}$; thiamine- $\mathrm{HCl}, \quad 100 \mu \mathrm{g} \mathrm{l}^{-1}$; biotine, $0.4 \mathrm{mg} \mathrm{l}^{-1}$; glucose $\mathrm{D}^{+}, 1.0 \mathrm{~g} \mathrm{l}^{-1}$; agar, $20 \mathrm{~g} \mathrm{l}^{-1} ; \mathrm{pH}$ before autoclaving: 5.5]. Where specified, the sources of $\mathrm{NH}_{4}^{+}$or $\mathrm{Ca}^{2+}$ ions were omitted from the nutrient medium. This first compartment was inoculated with 6 fungal plugs ( $6 \mathrm{~mm}$ dia) along the plate partition and will be referred to as the "nutrient compartment".

The second compartment was filled with high glucose water agar (glucose, $5 \mathrm{~g} \mathrm{l}^{-1}$; agar, $20 \mathrm{~g} \mathrm{l}^{-1}$ ) and with vermiculite (ca. $125 \mathrm{mg}$ ) that was gently dispersed in between two cellophane films so that mineral material could be easily recovered at the end of the experiment and chemically analysed without any mycelium on it [Fig. 1(A)]. This second compartment will be referred to as the "vermiculite compartment".

For scanning electron microscopy (SEM) observations, cellophane films were absent to allow direct colonization of vermiculite flakes by hyphae. The plates were kept in dark incubators at $25^{\circ} \mathrm{C}$ from 4 to 10 weeks for the mycelium to colonize the second compartment. Control plates were set up exactly in the same way except that they were not inoculated. Subsamples of saturated vermiculites were kept apart as original pre-experimental material for comparison with vermiculites from control plates.

\section{Vermiculite analysis}

$X$-ray diffraction. Small samples $(<10 \mathrm{mg})$ of vermiculite were collected from between the two cellophane films with a scalpel. Vermiculite particles were settled onto glass plates [ $(001)$ oriented sample slides]. Phyllosilicate d-spacings were assessed by $\mathrm{X}$-ray diffraction (Siemens 5000, copper anticathode $K_{x}=0.1541838 \mathrm{~nm}, 30 \mathrm{~mA}, 40 \mathrm{kV}$ ). The sample slide rotates from 1.5 to $20^{\circ} 2 \theta$ at a speed of $0.2 \mathrm{~s}$ for each $0.01^{\circ} 2 \theta$ step (analysis range: $2 \mathrm{~cm}$ dia). Relative humidity was maintained $<50 \%$. For each treatment. between 2 and 14 vermiculite samples from 2 to 7 replicate plates were analysed. After X-ray diffraction analysis some samples were individually resuspended in $2 \mathrm{ml}$ of a $1 \mathrm{M} \mathrm{KCl}$ solution and shaken for $1 \mathrm{~h}$ (performed twice). After washing with distilled water. a second X-ray diffraction analysis was performed on these samples. Samples, of which d-spacing did not completely collapse to $1.0 \mathrm{~nm}$ after this $\mathrm{KCl}$ treatment, were then gradually heated at $110^{\circ} \mathrm{C}$ (overnight), $220^{\circ} \mathrm{C}(5 \mathrm{~h}), 330^{\circ} \mathrm{C}(5 \mathrm{~h}), 440^{\circ} \mathrm{C}(5 \mathrm{~h})$ and $550^{\circ} \mathrm{C}(5 \mathrm{~h})$ until complete d-spacing closure. This method, adapted from Rouiller et al. (1980), did not allow a quantification of interlayer cations but gave access to their exchangeability for each individual small sample.

Inductively coupled plasma (ICP) spectrometry. Pooling vermiculite samples from 2 replicate plates was necessary for reliable analysis of exchangeable cations composition: $250 \mathrm{mg}$ of vermiculite were shaken in $7.5 \mathrm{ml}$ of a $1 \mathrm{M} \mathrm{KCl}$ solution for $1 \mathrm{~h}$ (performed twice) and washed with distilled water (Rouiller et al., 1980). Ca, Mg, Mn, Na, Fe, Al cations present in the $15 \mathrm{ml}$ extraction solution were quantified by ICP spectrometry (Jobin JY 38 plus). The sum of these cations was named "apparent CEC" (aCEC), it was expressed in mequiv for $100 \mathrm{~g}$ of 
mineral. As this would have required a specific analytical procedure and was not necessary for interpretation of the results, we did not check for $\mathrm{NH}_{4}^{+}$. Neither did we analyse $\mathrm{K}^{+}$, as a different extracting solution, such as $\mathrm{NaCl}$, would have been necessary.

$S E M$. Vermiculite samples were air-dried, goldcoated and observed under SEM (Philips SM 525, $25.6 \mathrm{kV}$ ) equiped with a microprobe (Link Energy Dispersing System).

\section{RESULTS}

\section{$\mathrm{NH}_{4}^{+}$-saturated vermiculite evolution}

Between 50 and 65 days after inoculation, the vermiculite compartments of the Petri dishes were fully colonized by $P$. involutus $\mathrm{COU}$ and the experiment was stopped at that time. Control vermiculites, from non-inoculated plates, were characterized by the same $1.04 \mathrm{~nm}$ peak as the original non-incubated material [Fig. 2(A, B)]. Therefore, $\mathrm{NH}_{4}^{+}$ions should be considered as retrograded or "fixed".

When no soluble $N$ was provided in the nutrient compartment. In this case the only source of $\mathrm{N}$ for mycelium nutrition was vermiculite interlayer $\mathrm{NH}_{4}^{+}$. Twenty-seven days after inoculation, the mycelium had colonized only half of the vermiculite compart- ment [Fig. 1(A)]. Then, the active growth of hyphae over vermiculite, compared to restricted development over the nutricnt modium (wherc only $\mathrm{N}$ was growth-limiting), suggested that retrograded $\mathrm{NH}_{4}^{+}$ had become available to the fungus [Fig. 1(A)]. X-ray diffractograms of vermiculite sequentially sampled along the fungal colony radius exhibited various stages of phyllosilicate evolution (Fig. 3), from almost collapsed d-spacings for vermiculite flakes collected under the hyphal tips (major peak at $1.05 \mathrm{~nm}$ with a $1.21 \mathrm{~nm}$ raised peak) [Fig. 3(A)] to expanded $\mathrm{d}$-spacings for vermiculite flakes collected under the oldest tissues along the plate partition ( 3 peaks at 1.05 , 1.21 and $1.44 \mathrm{~nm}$ ) [Fig. 3(F)]. Vermiculite interlayer expansion was, therefore, directly related to fungal progression.

Sixty-five days after inoculation, the X-ray diffractograms of all samples collected under fungal colonies differed from control vermiculite. Most of them ( 8 samples/ 14 samples analysed from 7 replicate Petri dishes) were characterized by 3 peaks, a major one at $1.44 \mathrm{~nm}$ with 2 minor peaks at 1.24 and $1.07 \mathrm{~nm}$ [Fig. 2(B), control vermiculite; Fig. 2(C), inoculated vermiculite]. The other remaining samples after incubation exhibited only 2 peaks: $2 / 14$ samples were characterized by a major peak at $1.47 \mathrm{~nm}$ and a minor one at $1.07 \mathrm{~nm}, 4 / 14$ samples by peaks at 1.19 and
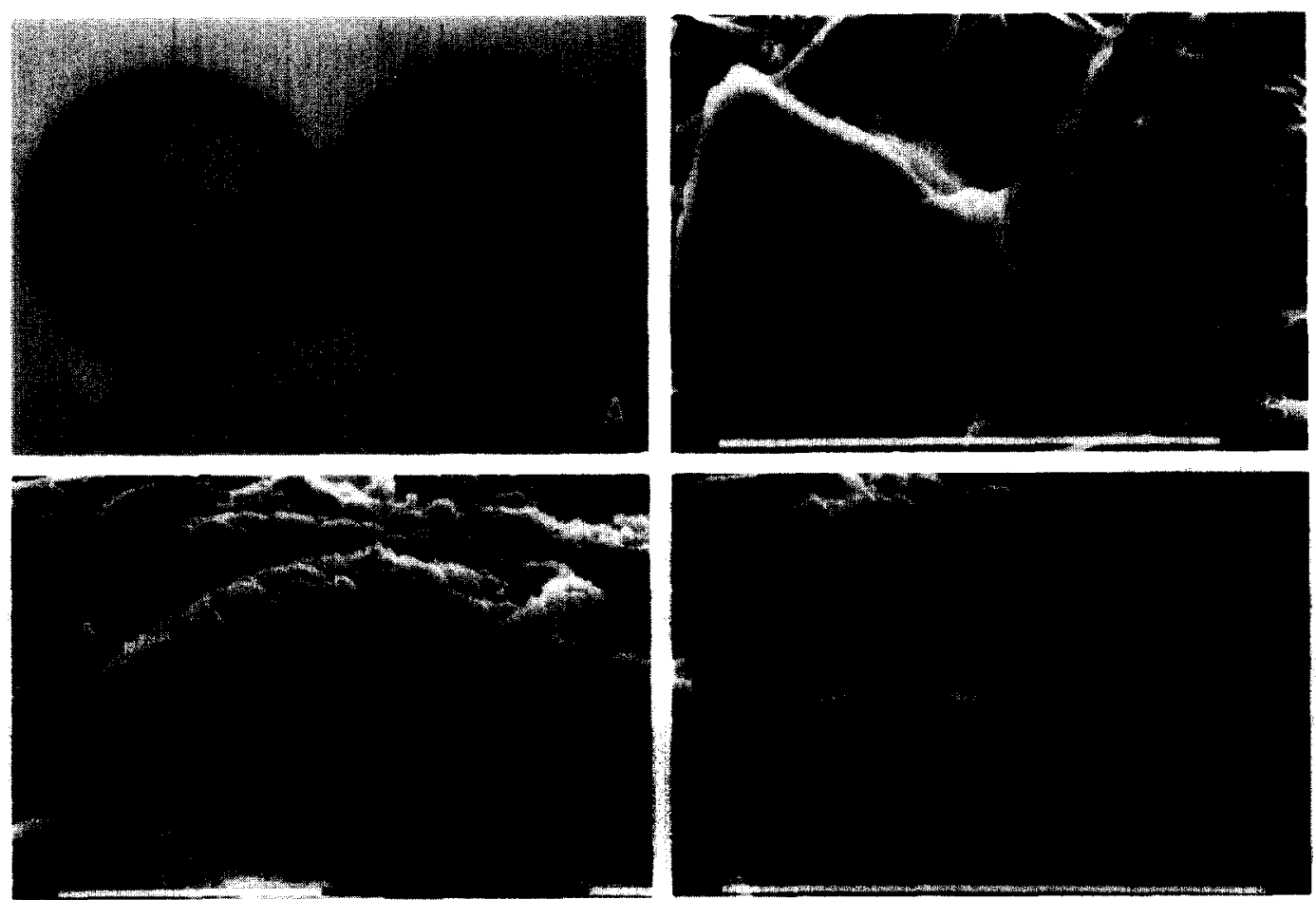

Fig. 1. Vermiculite flakes, saturated by $\mathrm{NH}_{4}^{+}(\mathrm{A}, \mathrm{B})$ or $\mathrm{Ca}^{2+}$ ions (C, D) and colonized by the ectomycorrhizal fungus $P$. involutus. On the inoculated plate (A, right), the fungal colony spreading out from the inoculum plugs (i) was very dense (+) over $\mathrm{NH}_{4}^{+}$-saturated vermiculite (v) compared to other areas in the Petri dish: the control plates were incubated in the absence of fungus (A, left). $\mathrm{NH}_{4}^{+}$-saturated flakes were heavily colonized by hyphae (B). Following fungal colonization, $\mathrm{Ca}^{2+}$-saturated flakes were embedded in a new crystalline material (C), including typical Ca oxalate crystals (D). Scale bars for SEM observations $=100 \mu \mathrm{m}(\mathrm{B}), 10 \mu \mathrm{m}$ (C) and $10 \mu \mathrm{m}$ (D). 


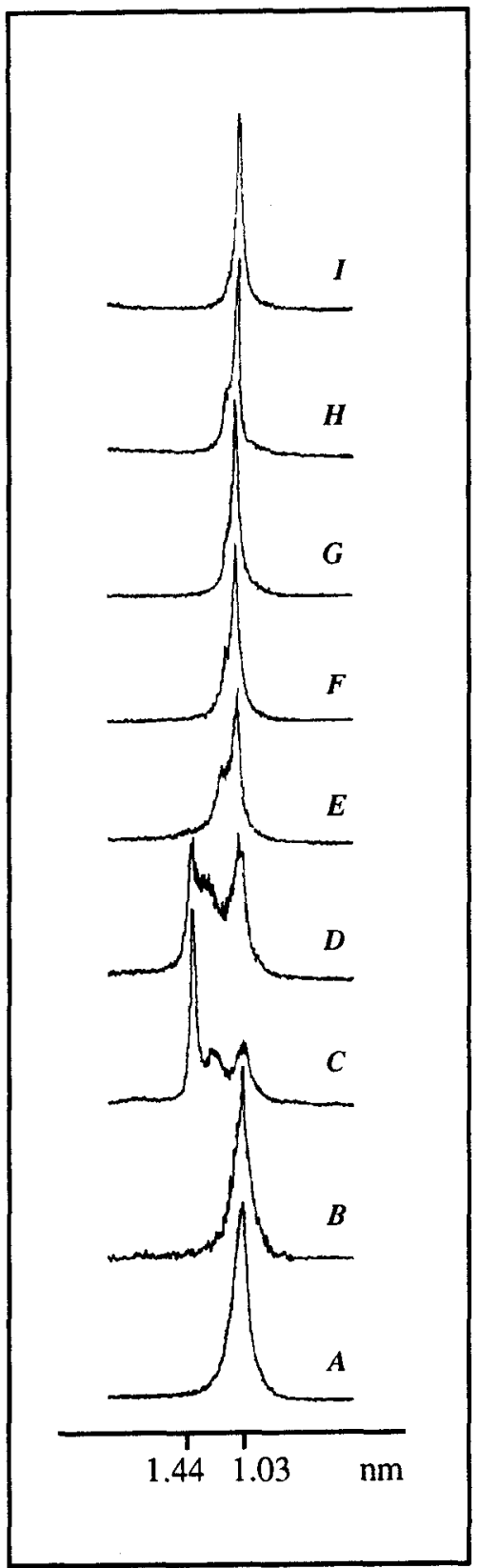

Fig. 2. X-ray diffractograms of initially $\mathrm{NH}_{4}^{+}$-saturated vermiculites (A) collected after a 65 -day incubation in the absence of fungal colony (B), or under a $P$. involutus colony (C). Vermiculite samples were treated with $1 \mathrm{M} \mathrm{KCl}$ to substitute interlayer cations with $\mathrm{K}^{+}(\mathrm{D})$ and heated to $110^{\circ} \mathrm{C}$ overnight (E) and then to $220^{\circ} \mathrm{C}(\mathrm{F}), 330^{\circ} \mathrm{C}(\mathrm{G}), 440^{\circ} \mathrm{C}(\mathrm{H})$ and $550^{\circ} \mathrm{C}$ (I) for $5 \mathrm{~h}$ until complete closure of the interlayer spaces.

$1.07 \mathrm{~nm}$ (diffractograms not shown). Although all $P$. involutus-inoculated vermiculite samples had been transformed by the end of the experiment, they formed a quite heterogenous population on the scale of a Petri dish.

Following X-ray diffraction analysis, 9 typically transformed samples [major peak at $1.44 \mathrm{~nm}$, minor peaks at 1.24 and $1.07 \mathrm{~nm}$; Fig. 2(C)] were individually treated with a $1 \mathrm{M} \mathrm{KCl}$ solution; d-spacings were then measured again to test the exchangeability of interfoliar cations. For each sample, some d-spacings collapsed back to $1.05 \mathrm{~nm}$, therefore, most vermiculite particles were closed again, but all samples still included some $1.38 \mathrm{~nm}$ d-spacings [Fig. 2(D)]. Gradual heating was necessary for complete interlayer collapsing. Most samples returned to $1.04 \mathrm{~nm}$ at $220^{\circ} \mathrm{C}$ but heating up to $550^{\circ} \mathrm{C}$ of the most evolved ones (2/9 samples) was necessary to allow complete interlayer space collapsing [Fig. 2(E-I)].

Minerals from 2 replicate plates were pooled together and treated with $\mathrm{KCl}$ to compare the exchangeable cation composition of control and evolved vermiculite (Table 1). In the $\mathrm{NH}_{4}^{+}$-saturated vermiculite (pre-experimental material) the sum of analysed exchangeable cations $(\mathrm{Ca}, \mathrm{Mg}, \mathrm{Mn}, \mathrm{Na}, \mathrm{Fe}$, Al ions) was $3.44 \pm 0.40$ mequiv $100 \mathrm{~g}^{-1}$, this fraction of the CEC was named aCEC. Therefore, the remaining fraction of the $\mathrm{CEC}$ is assumed to be occupied by $\mathrm{NH}_{4}^{+}$(about 156 mequiv $100 \mathrm{~g}^{-1}$ ). The mean aCEC value of vermiculite from non-inoculated control plates was $7.37 \pm 0.29$ mequiv $100 \mathrm{~g}^{-1}$, but after $P$. involutus COU colonization it reached

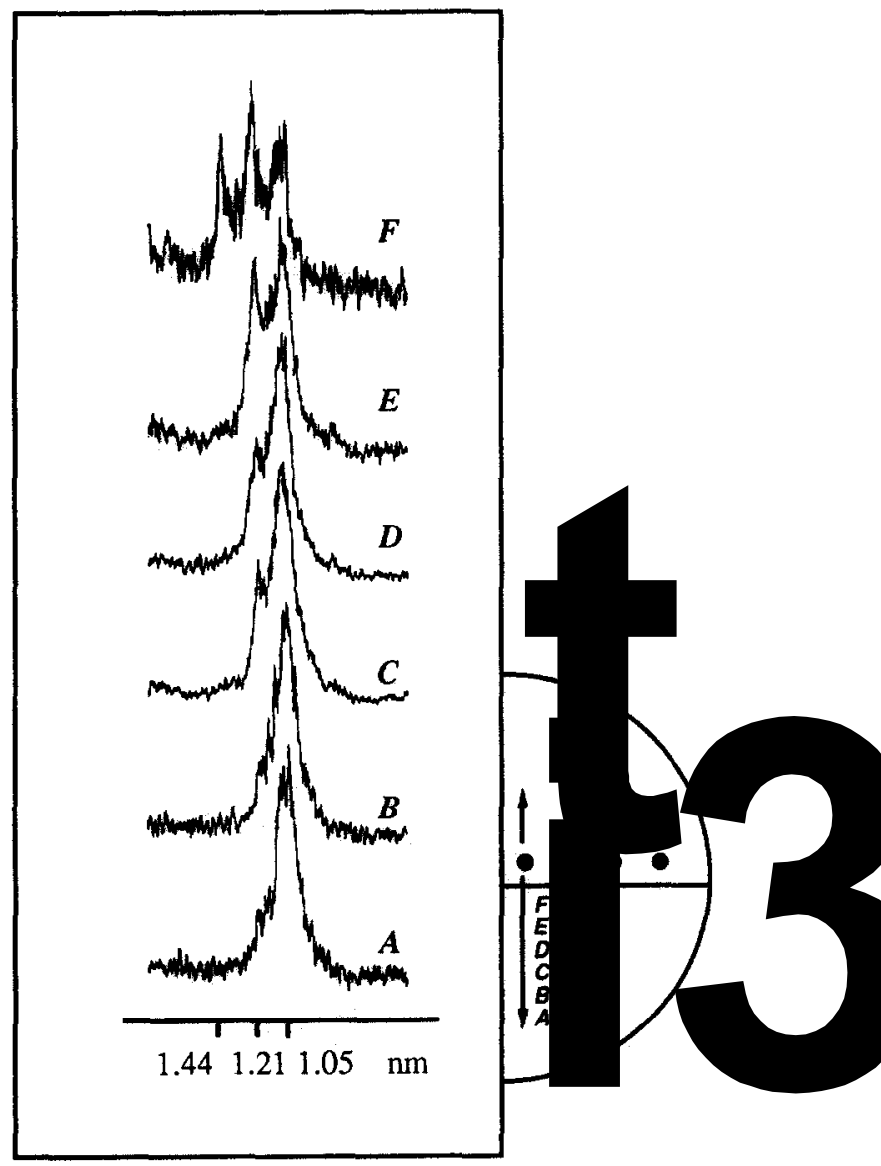

Fig. 3. X-ray diffractograms of initially $\mathrm{NH}_{4}^{+}$-saturated vermiculites collected at the edge of the $P$. involutus colony (A) and inward, towards the centre of the colony $(B-F)$. 
Table l. Exchangeable cation composition (mequiv $100 \mathrm{~g}^{-1}$ of vermiculite, mean $\pm \mathrm{SD} ; n=$ number of replicates) of initially NH; -saturated vermiculite after saturation (saturated vermiculite) and after a 65-day incubation without inoculation (control) or with inoculation by an ectomycorrhizal fungus: $P$. involutus $\mathrm{COU}(P, i),$.$R . luteolus (R, l),$.$B . edulis (B . e$.$) or C$. geophilum $(C . g$.); soluble $\mathrm{N}$ was not provided in the nutrient medium

\begin{tabular}{|c|c|c|c|c|c|c|c|}
\hline & $\mathrm{Ca}$ & $\mathbf{M g}$ & $\mathrm{Mn}$ & $\mathrm{Na}$ & $\mathrm{Fe}$ & Al & $\mathrm{aCEC}$ \\
\hline $\begin{array}{l}\text { Saturated vermiculite } \\
(n=3) \\
\text { Control }(n=5) \\
P . i .(n=2) \\
R . I .(n=1) \\
\text { B.e. }(n-1) \\
\text { C.g. }(n=1) \\
\end{array}$ & $\begin{array}{c}0.56 \pm 0.13 \\
4.12 \pm 0.34 \\
15.50 \pm 1.02 \\
11.51 \\
16.65 \\
9.20\end{array}$ & $\begin{array}{c}0.42 \pm 0.15 \\
1.70 \pm 0.04 \\
13.01 \pm 0.48 \\
11.83 \\
6.58 \\
4.66\end{array}$ & $\begin{array}{c}0.01 \pm 0.00 \\
0.02 \pm 0.00 \\
0.12 \pm 0.01 \\
0.11 \\
0.07 \\
0.05\end{array}$ & $\begin{array}{c}2.42 \pm 0.15 \\
1.42 \pm 0.20 \\
9.13 \pm 1.16 \\
5.90 \\
6.26 \\
5.32\end{array}$ & $\begin{array}{c}0.01 \pm 0.01 \\
0.00 \pm 0.00 \\
0.08 \pm 0.02 \\
1.57 \\
0.05 \\
0.06\end{array}$ & $\begin{array}{c}0.03 \pm 0.02 \\
0.11 \pm 0.07 \\
1.81 \pm 0.45 \\
1.62 \\
1.79 \\
0.54\end{array}$ & $\begin{array}{c}3.44 \pm 0.40 \\
7.37 \pm 0.29 \\
39.63 \pm 2.18 \\
32.54 \\
31.40 \\
19.83\end{array}$ \\
\hline
\end{tabular}

$39.63 \pm 2.18$ mequiv $100 \mathrm{~g}^{-1}$. Therefore approximately 32 mequiv $100 \mathrm{~g}^{-1}$ of the initial $\mathrm{NH}_{4}^{+}$cations have been substituted by $\mathrm{Ca}, \mathrm{Mg}, \mathrm{Na}$ and $\mathrm{Al}$ ions.

When soluble $N$ was provided in the nutrient compartment. When abundant soluble $\mathrm{N}\left(\mathrm{NH}_{4} \mathrm{SO}_{4}\right)$ was added to the nutrient medium, $P$. involutus grew at the same rate in both compartments of the Petri dish, and was still able to induce vermiculite transformation. Fifty days after inoculation, all vermiculite samples analysed differed from control vermiculite (13 samples from 6 replicate Petri dishes). Three peaks were observed in most cases (11/13 samples) at $1.42,1.25$ and $1.05 \mathrm{~nm}$, and 2 peaks at 1.42 and $1.05 \mathrm{~nm}$ for the other 2 samples (X-ray diffractograms not shown). All samples treated with $1 \mathrm{M} \mathrm{KCl}$ only partially returned to $1.06 \mathrm{~nm}$, some interlayer spaces remained open at $1.33 \mathrm{~nm}$ (X-ray diffractograms not shown) and collapsed to $1.04 \mathrm{~nm}$ after heating at $220^{\circ} \mathrm{C}$ as previously described in the absence of soluble $\mathrm{N}$.

Fungal strain comparisons. Five other ectomycorrhizal fungi grown without soluble $\mathrm{N}--R$. luteolus, $B$. edulis, C. geophilum, $P$. tinctorius, $P$. involutus NAU--could also transform vermiculite. Such transformations were identified as expansion of interlayer spaces of $\mathrm{NH}_{4}^{+}$-saturated vermiculite $(\mathrm{X}$-ray diffractograms not shown). aCEC (only determined following $R$. luteolus, $B$. edulis and $C$. geophilum colonization) increased in a way similar to that measured after $P$. involutus COU growth (Table 1): $\mathrm{NH}_{4}^{+}$ions were mainly replaced by $\mathrm{Na}, \mathrm{Ca}, \mathrm{Al}$ and $\mathrm{Mg}$ ions.

\section{$C a^{2+}$-saturated vermiculite evolution}

Seventy days after inoculation, Petri dishes were fully colonized by $P$. involutus $\mathrm{COU}$. The presence or absence of soluble $\mathrm{Ca}$ in the nutrient compartment of the Petri dish did not apparently affect fungal growth. At the end of the experiment, all X-ray diffractograms of vermiculite from non-inoculated control plates were characterized by a single peak at $1.46 \mathrm{~nm}$ as in the original pre-experimental material [Fig. 4(A, B)].

When no soluble $\mathrm{Ca}$ was provided in the nutrient compartment. Modified X-ray diffractograms related to fungal colonization were found in 6 out of 8 samples analysed from 5 replicate Petri dishes [Fig. 4(C)]. The major peak was at $1.45 \mathrm{~nm}$, but a minor peak could be observed at $1.27 \mathrm{~nm}$. These too small samples were not individually checked for cation exchangeability in $1 \mathrm{M}$ $\mathrm{KCl}$ solution.

Total vermiculite from 2 replicate plates was pooled together and treated with $1 \mathrm{M} \mathrm{KCl}$ to analyse the exchangeable cation composition (Table 2). We referred to this sum of cations aCEC (see Materials and Methods). The aCEC of the original pre-experimental material was $155.43 \pm 4.47$ mequiv $100 \mathrm{~g}^{-1}$, $98.95 \%$ of it being occupied by $\mathrm{Ca}$ ions $\left(153.80 \pm 4.33\right.$ mequiv $\left.100 \mathrm{~g}^{-1}\right)$. In control non-inoculated plates the sum of exchangeable cations remained stable $\left(154.51 \pm 1.53\right.$ mequiv $\left.100 \mathrm{~g}^{-1}\right)$ but $\mathrm{Ca}$ saturation was then reduced to $87.53 \%$ $\left(135.24 \pm 1.441\right.$ mequiv $\left.100 \mathrm{~g}^{-1}\right)$ : this $\mathrm{Ca}$ release was compensated by $\mathrm{Mg}$ and $\mathrm{Na}$ ions and by traces of $\mathrm{Al}$ ions. $\mathrm{Mg}$ and $\mathrm{Na}$ ions could originate from agar or

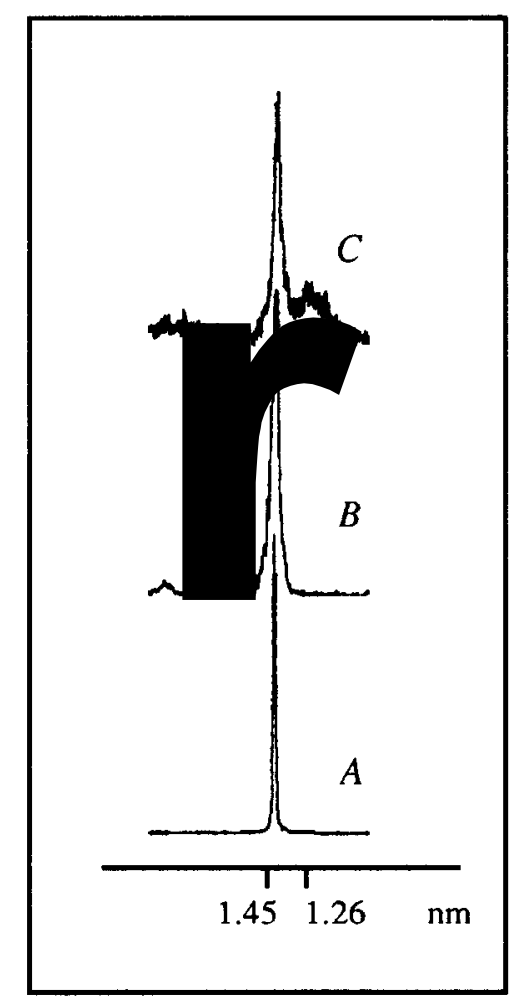

Fig. 4. X-ray diffractograms of initially $\mathrm{Ca}^{2+}$-saturated vermiculites (A) collected after a 70-day incubation in the absence of fungal colony (B), or under a $P$. involutus colony $(\mathrm{C})$. 
Table 2. Exchangeable cation composition (mequiv $100 \mathrm{~g}^{-1}$ of vermiculite, mean $\pm \mathrm{SD} ; n=$ number of replicates) of initially Ca ${ }^{2+}$-saturated vermiculite after saturation (saturated vermiculite) and after a 70-day incubation without inoculation (control) or with inoculation by the ectomycorrhizal fungus $\boldsymbol{P}$. involutus $(\boldsymbol{P}, \boldsymbol{i}$ ); soluble $\mathrm{Ca}$ was provided $(+\mathrm{Ca})$ or omitted $(-\mathrm{Ca})$ in the nutrient medium

\begin{tabular}{lccccccc}
\hline \multicolumn{1}{c}{} & $\mathrm{Ca}$ & $\mathrm{Mg}$ & $\mathrm{Mn}$ & $\mathrm{Na}$ & $\mathrm{Fe}$ & $\mathrm{Al}$ & $\mathrm{aCEC}$ \\
\hline Saturated vermiculite & & & & & & \\
$(n=3)$ & $153.80 \pm 4.33$ & $0.34 \pm 0.12$ & $0.02 \pm 0.00$ & $1.26 \pm 0.02$ & $0.00 \pm 0.00$ & $0.01 \pm 0.02$ & $155.43 \pm 4.47$ \\
Control $(n=2)$ & $135.24 \pm 1.44$ & $5.90 \pm 0.86$ & $0.08 \pm 0.01$ & $12.58 \pm 0.54$ & $0.00 \pm 0.00$ & $0.71 \pm 0.24$ & $154.51 \pm 1.53$ \\
$P . i .(-\mathrm{Ca})(n=1)$ & 111.09 & 12.66 & 0.12 & 8.03 & 0.82 & 2.68 & 135.40 \\
$P . i .(+\mathrm{Ca})(n=1)$ & 119.93 & 12.33 & 0.11 & 12.65 & 0.26 & 2.45 & 147.73 \\
\hline
\end{tabular}

ccllophane but, as our culture device was Al-free, Al ions must originate from the vermiculite crystal lattice. The aCEC of vermiculite collected under $P$. involutus mycelium was not drastically modified (135.40 mequiv $100 \mathrm{~g}^{-1}$ ), Ca saturation was slightly reduced to $81.28 \% \quad\left(111.09\right.$ mequiv $\left.100 \mathrm{~g}^{-1}\right)$, a 2.1-fold increase in $\mathrm{Mg}^{2+}$ concentration and a 3.8-fold increase in $\mathrm{Al}^{3+}$ concentration were detected.

Following such $\mathrm{KCl}$ treatment of total vermiculite originating from 2 replicate plates, d-spacings of inoculated minerals collapsed to $1.09 \mathrm{~nm}$ just as with the control ones (diffractograms not shown). Therefore, there was no evidence of no nonexchangeable complexes remaining in the interlayer spaces. The difference in aCEC (154-135 mequiv) between control and inoculated vermiculites could, therefore, only be explained by non-measured exchangeable cations.

As the quantity of $\mathrm{Na}^{+}$interlayer cations did not increase, we can infer that the $1.27 \mathrm{~nm}$ shoulder was due to some $1.0 \mathrm{~nm}$ d-spacings mixed with $1.4 \mathrm{~nm}$ d-spacings. $\mathrm{K}^{+}$and $\mathrm{NH}_{4}^{+}$cations are the only cations capable of such a closure; as these ions were not analysed in the $\mathrm{KCl}$ extraction solution, they could also explain the slight decrease in aCEC. The phyllosilicate might therefore have evolved towards a $\mathrm{Ca}-\mathrm{K}-\mathrm{NH}_{4}$ interstratified vermiculite. A similar change was observed with a vermiculite treated with bi-ionic $\mathrm{K}^{+}-\mathrm{Mg}^{2+}$ solutions (Martin de Vidales et al., 1991).

SEM observations showed that initially $\mathrm{Ca}^{2+}$-saturated vermiculite flakes directly colonized by mycelium were embedded within a Ca deposit [Fig. 1(C)] in which the typical $\mathrm{Ca}$ oxalate crystal structure could be recognized [Fig. 1(D)]. This new material was therefore assumed to be $\mathrm{Ca}$ oxalate; this hypothesis was confirmed by microanalysis as only $\mathrm{Ca}$ ions were detected in it. The only source of $\mathrm{Ca}$ being the vermiculite interlayer cations, this gave secondary evidence of fungal abilitity to mobilize interlayer $\mathrm{Ca}$ ions. Such neoformations were never observed on colonized $\mathrm{NH}_{4}^{+}$-saturated vermiculite [Fig. 1(B)].

When $\mathrm{Ca}^{2+}$-saturated vermiculite was isolated from mycelium by cellophane films, white deposits that showed the typical structure of Ca oxalate crystals under photonic microscopy were observed on the cellophane films, and on the vermiculite flakes. This raises the question of their eventual dissolution during the shaking of the mineral with $1 \mathrm{M} \mathrm{KCl}$ for interlayer cations extraction and aCEC analysis. As we do not have a precise answer to this question, the number of mequiv $100 \mathrm{~g}^{-1}$ of $\mathrm{Ca}$ ions thought to be originating from the interlayer spaces might therefore be overestimated. If so, fungal Ca mobilisation would be underestimated.

When soluble $\mathrm{Ca}$ was provided in the nutrient compartment. No modification of vermiculite d-spacings related to fungal colonization was detected ( 6 samples from 3 replicate Petri dishes analysed). The aCEC of the vermiculite collected under $P$. involutus mycelium was quite similar to that measured for the soluble Ca-free treatment, and the measured ca desaturation was in a similar range (Table 2).

Fungal strain comparisons. Without soluble $\mathrm{Ca}$ in the nutrient medium, the vermiculite exposed to $P$. tinctorius for 100 days showed the same trends of d-spacing evolution as with $P$. involutus COU: $3 / 5$ samples from 5 replicate Petri dishes were characterized by a shoulder at $1.27 \mathrm{~nm}$ rising up from a $1.46 \mathrm{~nm}$ peak.

\section{DISCUSSION}

Ectomycorrhizal fungi have access to $\mathrm{NH}_{4}^{+}$and $\mathrm{Ca}^{2+}$ ions trapped in between the vermiculite 2:1 layers. As vermiculite samples were separated from the mycelium by cellophane films, soluble fungal exudates are responsible for phyllosilicate weathering. $\mathrm{NH}_{4}^{+}$ ions, usually considered as retrograded, were mobilized from the interlayer spaces and replaced by $\mathrm{Mg}^{2+}, \mathrm{Al}^{3+}, \mathrm{Ca}^{2+}$ and $\mathrm{Na}+$ ions. $\mathrm{Ca}^{2+}$ ions were mainly replaced in interlayer spaces by $\mathrm{Mg}^{2+}$ and $\mathrm{Al}^{3+}$ ions but protons, $\mathrm{K}^{+}$or $\mathrm{NH}_{4}^{+}$ions could also have contributed to $\mathrm{Ca}^{2+}$ substitutions.

The access of microorganism to vermiculite $\mathrm{N}$ has only been investigated for nitrifying bacteria (Nómmik, 1957; Simon-Sylvestre et al., 1991). Ca ${ }^{2-}$ release from Ca-saturated vermiculite by saprophytic fungi has been reported by Robert and Chenu (1992), but this is the first report concerning ectomycorrhizal fungi in pure culture.

Exchangeable $\mathrm{Al}^{3}$ ions were detected in the interlayer spaces of $\mathrm{NH}_{4}^{+}$-saturated vermiculite after exposure to ectomycorrhizal fungi. It strongly suggests that the crystal lattice has been weathered, as it was the only $\mathrm{Al}^{3-}$ source in the experimental device. Some of the $\mathrm{NH}_{4}$-saturated vermiculite collected under the mycelium did not collapse to a peak at $1.0 \mathrm{~nm}$ in spite of $\mathrm{K}$-saturation and $110^{\circ} \mathrm{C}$ heating. These non-exchangeable "wedges" prevent the collapse of the opened structure and render the transformation of the 
phyllosilicate irreversible. Therefore, some $\mathrm{NH}_{4}^{+}$-saturated particles have probably evolved under mycelium towards an hydroxy-aluminous vermiculite. Such crystallographic and crystallochemical changes necessarily involved an acid dissolution of part of the mica structure. Our experimental approach does not give access to an eventual complete mineral dissolution phenomenon: however, this reaction can not be excluded.

A cation addition or depletion in the nutrient medium does not seem to affect fungal mobilization potential. Therefore such potential may be more constitutive than inducible.

When $\mathrm{Ca}^{2+}$ ions were mobilized from vermiculite, $\mathrm{Ca}$ oxalate crystal accumulation was easily detected. Oxalic acid is a strong complexing agent (Robert et al., 1979) frequently associated with mineral weathering by lichens or fungi (Graustein et al., 1977; Jones and Wilson, 1985;Robert and Berthelin, 1986). Oxalic acid excretion by ectomycorrhizal fungi including $P$. involutus has been reported many times (e.g. Lapeyrie et al., 1987; Entry et al., 1992; Griffiths et al., 1994). Cromack et al. (1979) found higher oxalate concentrations and evidence for advanced clay weathering in Hysterangium setchellii mats of northwest U.S. soils. It is therefore not surprising that oxalate appears involved in the alteration of vermiculite by $P$. involutus. This should not exclude the possible involvement of other fungal organic-complexing molecules, siderophore-like, so far unidentified, as suggested by Ochs et al. (1993) when comparing $\gamma-\mathrm{Al}_{2} \mathrm{O}_{3}$ solubilization by mycorrhizal and non-mycorrhizal plant exudates. The ectomycorrhizal fungi $P$. involutus and $P$. tinctorius are also known to release a reducing substance (reduction of manganese oxide) (Cairney and Ashford, 1991). Robert (1971) experimentally verified the effect of oxido-reduction phenomenon in phyllosilicate transformation (vermiculitization).

Figure 1(C, D) shows initially $\mathrm{Ca}^{2+}$-saturated vermiculite flakes in a dense network of hyphae covered by $\mathrm{Ca}$ oxalate crystals. Figure 1(B) shows bare hyphae in contact with initially $\mathbf{N H}_{4}^{+}$-saturated vermiculite flakes. We can infer that oxalate produced by these hyphae has reacted with $\mathrm{Fe}$ and $\mathrm{Al}$ ions originating from the vermiculite crystal lattice, thus accelerating weathering. This chemical reaction coupled with the large sink for $\mathrm{N}$ constituted by the mycelium could have led to the massive transformation of the $\mathrm{NH}_{4}^{+}$-saturated vermiculite. In contact with $\mathrm{Ca}^{2+}$-saturated vermiculite, Ca oxalate formation is promoted by $\mathrm{Ca}^{2+}$ from vermiculite, impeding $\mathrm{Fe}$ and $\mathrm{Al}$ ions complexation. While oxalic acid could enhance the weathering of the $\mathrm{NH}_{4}^{+}$-saturated vermiculite, it might be ineffective on $\mathrm{Ca}^{2+}$-saturated vermiculite.

In forest stands, tree species have an important action on soil functioning and vermiculite weathering (Ranger et al., 1990). We established that some ectomycorrhizal fungi have access, in vitro, to various ions from the phyllosilicate interlayers or crystal lattices. Endomycorrhizas compared to non-mycorrhizal roots are able to promote biotite weathering (Mojallali and Weed, 1978; Berthelin and Leyval, 1982). Here, the quantitative significance of such symbiotic mobilization and weathering by ectomycorrhizal fungi still has to be assessed in situ and in association with ectomycorrhizal plants. Indeed, not only mycorrhizal fungi and ectomycorrhizas but saprophytic microorganisms and non-mycorrhizal roots also interact with soil minerals.Interestingly, while oxalic acid may play an important role in mineral weathering by ectomycorrhizal fungi, widely different plant families have developed similar biogeochemical mechanisms, as non-mycorrhizal proteoid roots of Banksia release citric acid into their rhizospheres (Grierson, 1992).

Acknowledgements-We thank Anne-Marie Jaunet (Laboratoire de Sciences du Sol 2, INRA, Versailles) who kindly provided facilities and assistance for the SEM and microprobe.

\section{REFERENCES}

Arnebrant K., Ek H., Findlay R. and Söderström B. (1993) Nitrogen translocation between Alnus glutinosa (L.) Gaertn. seedlings inoculated with Frankia sp. and Pinus contorda Doug. ex Loud seedlings connected by a common ectomycorrhizal mycelium. New Phytologist 124, 231-242.

Berthelin J. and Leyval C. (1982) Ability of symbiotic and non-symbiotic rhizospheric microtlora of maize ( $\mathrm{Zea}$ mays) to weather micas and to promote plant growth and plant nutrition. Plant and Soil 68, 369-377.

Bousquet N., Mousain D. and Salsac L. (1985) Use of phytate by ectomycorrhizal fungi. In Physiological and Genetical Aspects of Mycorrhizae; Proceedings of the First European Symposium on Mycorrhizae (V. Gianinazzi-Pearson and S. Gianinazzi, Eds), pp. 363-368. INRA, Paris.

Bowen G. D. (1973) Mineral nutrition of ectomycorrhizae. In Ectomycorrhizae-Their Ecology and Physiology (G. C. Marks and T. T. Kozlowski, Eds), pp. 151-197. Academic Press, New York.

Cairney J. W. G. and Ashford A. E. (1991) Release of a reducing substance by the ectomycorrhizal fungi Pisolithus tinctorius and Paxillus involutus. Plant and Soil 135, 147-150.

Cromack K. Jr, Sollins P., Graustein W. C., Speidel K., Todd A. W., Spycher G., Li C. Y. and Todd R. L. (1979) Calcium oxalate accumulation and soil weathering in mats of the hypogeous fungus Hysterangium crassum. Soil Biology \& Biochemistry 11, $463-468$.

Dixon R. K. and Hiol-Hiol F. (1992) Mineral nutrition of Pinus caribea and Eucalyptus camaldulensis seedlings inoculated with Pisolithus tinctorius and Thelephora terrestris. Communications in Soil Science and Plant Analysis 23, 1387-1396.

Eckhard F. E. W. (1985) Solubilization, transport, and deposition of mineral cations by microorganismsefficient rock weathering agents. In The Chemistry of Weathering (J. I. Drever, Ed.), pp. 161-173. Reidel, Norwell.

Entry J. A., Rose C. L. and Cromack K. (1992) Microbial biomass and nutrient concentrations in hyphal mats of the ectomycorrhizal fungus Hysterangium setchellii in a coniferous forest soil. Soil Biology \& Biochemistry 24, 447-453.

Graustein W. C., Cromack K. Jr and Sollins P. (1977) Calcium oxalate: occurence in soils and effect on nutrient and geochemical cycles. Science 198, 1252-1254. 
Grierson P.F. (1992) Organic acids in the rhizosphere of Banksia integrifolia L.F. Plant and Soil 144, 259-265.

Griffiths R. P., Baham J. E and Caldwell B. A.. (1994) Soil solution chemistry of ectomycorrhizal mats in forest soil. Soil Biology \& Biochemistry 26, 331-337.

Harley J. L. and Smith S. E. (1983) Mycorrhizal Symbiosis. Academic Press, London.

Hinsinger P. and Jaillard B. (1993) Root-induced release of interlayer potassium and vermiculitization of phlogopite as related to potassium depletion in the rhizosphere of rye grass. Journal of Soil Science 44, 525-534.

Jones D. and Wilson M. J. (1985) Chemical activity of lichens on mineral surfaces-a review. International Biodeterioration 21, 99-104.

Lapeyrie F., Chilvers G. A. and Bhem C. A. (1987) Oxalic acid synthesis by the mycorrhizal fungus Paxillus involutus. New Phytologist 106, 139-146.

Lapeyrie F., Ranger J. and Vairelles D. (1991) Phosphates solubilizing activity of ectomycorrhizal fungi in vitro. Canadian Journal of Botany 69, 342-346.

Le Tacon F., Garbaye J., Bouchard D., Chevalier G., Olivier J. M., Guimberteau J., Poitou, N and Frochot H. (1988) Field results from ectomycorrhizal inoculation in France. In Canadian Workshop on Mycorhizae in Forestry (M. Lalonde and Y. Piche, Eds), pp. 51-74. Université Laval-Québec.

Leyval C. and Berthelin J. (1986) Comparison between the utilization of phosphorus from insoluble mineral phosphates by ectomycorrhizal fungi and rhizobacteria. In Physiological and Genetical Aspects of Mycorrhizae; Proceeding of First European Symposium on Mycorrhizae (V. Gianinazzi-Pearson and S. Gianinazzi, Eds), pp. 345349. INRA, Paris.

Leyval C. and Berthelin J. (1991) Weathering of a mica by roots and rhizospheric microorganisms of Pine. Soil Science Society of America Journal 55, $1009-1016$.

Martin de Vidales J. L., de la Calle C. and Pons C. H. (1991) Interstratification $\mathrm{K}-\mathrm{Mg}$ dans les vermiculites. Comportement particulier de la vermiculite de Malawi. Clay Minerals 26, 571-576.

Mojallali H. and Weed S.B. (1978) Weathering of micas by mycorrhizal roots of soybean. Soil Science Society of America Journal 42, 367-372.

Nguyen C., Yan W., Le Tacon F, and Lapeyrie F. (1992) Genetic variability of phosphate solubilizing activity by monokaryotic and dikaryotic mycelia of the ectomycorrhizal fungus Laccaria bicolor (Maire) P. D. Orton. Plant and Soil 143, 193-199.
Nõmmik H. (1957) Fixation and defixation of ammonium in soils. Acta Agriculturae Scandinavica 7, 395-436.

Ochs M., Brunner I., Stumm W. and Cosovic B. (1993) Effects of root exudates and humic substances on weathering kinetics. Water, Air, and Soil Pollution 68, 213-229.

Paul E. A. and Clark F. E. (1989) Suil Microbiology and Biochemistry. Academic Press, San Diego, CA.

Ranger J., Robert M., Bonnaud P. and Nys C. (1990) Les minéraux-test, une approche expérimentale in situ de l'altération biologique et $\mathrm{du}$ fonctionnement des écosystèmes forestiers. Effets des types de sols et des essences feuillues et résineuses. Annales des Sciences Forestières 47, 529-550.

Robert M. (1971) Etude expérimentale de l'évolution des micas (biotites). I-Les aspects du processus de vermiculisation. Annales Agronomiques 22, 43-93.

Robert M. and Berthelin J. (1986) Role of biological and biochemical factors in soil mineral weathering. In Interactions of Soil Minerals with Natural Organics and Microbes (P. M. Huang and M. Schnitzer, Eds), pp. 453-495. Soil Science Society of America, Madison, WI

Robert M. and Chenu C. (1992) Interactions between soil minerals and microorganisms. In Soil Biochemisiry, Vol. 7 (G. Stotzky and J. M. Bollag, Eds), pp. 307-404. Marcel Dekker, New York.

Robert M., Razzaghe H., Vincente M. A. and Veneau G. (1979) Rôle du facteur biochimique dans l'altération des minéraux silicatés. Science du Sol 17, 153 174.

Rouiller J., Guillet B. and Bruckert S. (1980) Cations acides échangeables et acidité de surface. Approche analytique et incidence pédogénétique. Science du Sol 18, 161-175.

Simon-Sylvestre G., Robert M., Vencau G. and Beaumont A. (1991) Nitrification related to acidification and silicate weathering. In Developments in Geochemistrv, Diversity of Ennironmental Biogeochemistry (I. Berthelin, Ed.), pp. 371-378. Elsevier, Amsterdam.

Stevenson F. J., Dhariwal A. P. S. and Choudhri M. B. (1958) Further evidence for naturally occuring fixed ammonium in soils. Soil Science 85, 42-46.

Thomas G. W., Clarke C. A., Mosse B. and Jackson R. M (1982) Source of phosphate taken up from two soils by mycorrhizal (Telephora terrestris) and non-mycorrhizal Picea sitchensis seedlings. Soil Biology \& Biochemistry 14, 73-75. 